\title{
Preliminary studies on the immunomodulatory and antioxidant properties of Selaginella species
}

\author{
V. Gayathri, V.V. Asha*, A. Subramoniam
}

Tropical Botanic Garden and Research Institute, Pacha-Palode Thiruvananthapuram - 695 562,

Kerala

*Rajiv Gandhi Centre for Biotechnology, Poojapura,

Thiruvananthapuram, Kerala

Received: 25.4.2005

Revised: 1.8.2005

Accepted: 2.8.2005

Correspondence to:

A. Subramoniam

E-mail:

asubramoniam@yahoo.com

\begin{abstract}
Objective: To evaluate the immunomodulatory and antioxidant properties, if any, of Selaginella involvens, S. delicatula and S. wightii.

Materials and Methods: Immunomodulatory activity of the whole plants (water suspension) was studied in mice immunized with sheep RBC. The plant extracts were tested for their effect on lipid peroxidation (in vitro and in vivo in mice), and for in vitro hydroxyl radical scavenging activity. The most promising extract (water extract of $S$. involvens) was evaluated for its short-term toxicity in mice.

Results: The dried suspension $(500 \mathrm{mg} / \mathrm{kg}$ ) of the three plants did not influence humoral antibody titre and the number of antibody secreting cells in the mouse spleen. However, the plant suspensions as well as the water extracts (and not the other extracts) of the plants remarkably increased the weight of thymus in adult mice, and not in suckling mice. This effect was very marked in the case of $S$. involvens compared to the other two species. Although the water extract of all the three plants showed varying degrees of antioxidant activity, the antilipid peroxidation activity of $S$. involvens (water extract) was remarkable $\left[\mathrm{EC}_{50}: 2 \mu \mathrm{g} / \mathrm{ml}\right]$. This extract did not exhibit any conspicuous toxicity in mice in general, short-term toxicity evaluation. At high dose, serum cholesterol level was significantly reduced.

Conclusion: Out of the three Selaginella species studied, the water extract of $S$. involvens has promising thymus growth stimulatory activity in adult mice and remarkable antilipid peroxidation property; these observations are of interest in view of tribal and folklore belief that this plant prolongs life span.
\end{abstract}

KEYWORDS: Medicinal pteridophytes, Selaginellaceae, thymus

\section{Introduction}

Although many ferns, pteridophytes, are used in ethnomedical practices in remote villages in India, most of them are not pharmacologically evaluated. ${ }^{[1]-[3]}$ There is an urgent need to determine the true therapeutic value of medicinal pteridophytes. Among pteridophytes, Selaginella [family: Selaginellaceae] is an important, fully unexplored genus with regard to their medicinal properties. Some of the species of the genus are used in folk medicine as a guarded secret. ${ }^{[2],{ }^{[4]}} S$. involvens (SW) Spring, S. delicatula (Devs.) Alston, and $S$. wightii Hieron are the three important Selaginella species found in the Western Ghats of Kerala. S. involvens is an epiphytic fern which also grows as lithophytes and terrestrial plants. It is said to possess the property of prolonging life and ameliorating old age-related health problems including infections. [2] [5], [6] $S$. delicatula is used in ethnomedicine for healing external ulcers and it is found throughout the southern parts of Western Ghats partially in shaded and moist areas. $S$. wightii is a rare prostrate fern found in open rocky areas. It is used in folk medicine to treat urinary infections. ${ }^{[2] .14]}$ The present study reports the immunomodulatory and antioxidant activity of these plants in relation to the traditional use of $S$. involvens.

\section{Materials and Methods}

Animals

Adult Swiss albino mice (25-30 g, body weight) maintained in our animal house under standard conditions were used. Animals were fed with standard rodent pellet and water ad libitum. Our animal house and breeding facility have been registered with Committee for the Purpose of Control and Supervision of Experiments on Animals (CPCSEA), Government of India and the CPCSEA guidelines were followed [IAEC approval obtained].

\section{Preparation of plant suspension and extracts}

The plants were collected from the wild and identified with the help of pteridophyte taxonomists of Tropical Botanic Garden and Research Institute (TBGRI) and specimen samples were preserved. The whole plant was dried, powdered, ground in $2 \%$ gum acacia into a fine paste and suspended to the 
desired concentration with $2 \%$ gum acacia for oral administration.

To prepare water extract, the dried plant powder was extracted with distilled water $(5 \mathrm{~g} / 100 \mathrm{ml})$ with constant stirring for $4 \mathrm{~h}$ and then filtered through a filter paper. Residue was again extracted using the same method as above with water. The combined filtrate was freeze-dried. The alcohol extract of the plant powder was prepared similarly using ethyl alcohol instead of distilled water. However, in this case, the combined extract was evaporated to dryness in a rotary evaporator under reduced pressure at $40^{\circ} \mathrm{C}$ as described elsewhere; ${ }^{[7]}$ and the yield of the extract was determined. The hexane extracts of the powder was prepared as above using n-hexane instead of alcohol. However, to ensure complete extraction, $2 \mathrm{~g}$ powder was extracted with $100 \mathrm{ml}$ hexane and the process was repeated three times. The filtrates from the extractions were combined and dried in a rotary evaporator under reduced pressure at $40^{\circ} \mathrm{C}$. The yield of the hexane extract was determined.

\section{Immunomodulatory property}

This was done as described elsewhere..$^{[8], ~}{ }^{19]}$ Briefly, groups of six mice were immunized by injecting (i. p.) $0.2 \mathrm{ml}$ of sheep RBC $\left(5 \times 10^{9}\right.$ cells $\left./ \mathrm{ml}\right)$ on day 0 . The fern suspension was administered orally $(500 \mathrm{mg} / \mathrm{kg})$ on days $-3,-2,-1,0,+1,+2$ and +3 . A reasonably high dose, i.e., $500 \mathrm{mg}($ dry $\mathrm{wt}) / \mathrm{kg}$ of the whole plant was used.

Control group received 1\% gum acacia in an identical manner. On day 7, after immunization, blood was collected to determine hemagglutination antibody titre,$^{[8]}$ leucocyte count and spleen for plaque forming cells. ${ }^{[10]}$ Macrophages were separated from peritoneal exudate cells (collected using cold RPMI-1640 medium containing heparin) by adhering on glass surfaces at $37^{\circ} \mathrm{C}$ in heparin free medium. The adhered cells were collected in cold medium containing heparin and counted using hemocytometer. The weight of thymus was also determined.

Since the thymus weight was influenced by the herbal drugs in the preliminary observations, effect of different periods of treatment as well as age of animals on the same were studied. For this purpose, 3, 9 and 16 weeks old male mice were selected and each age group was divided into four groups. Group 1 served as control and groups 2-4 received treatment on days 1, 2 and 6, respectively. [In the preliminary study, $100 \mathrm{mg} / \mathrm{kg}$ water extract of $S$. involvens, and not alcohol and hexane extracts, stimulated thymus growth. Hence $100 \mathrm{mg} / \mathrm{kg}$ water extract was tested in these studies].

To study the effect of different doses of water extract of each plant, four groups each containing three nine-week-old mice were used. Group 1 served as control and received water while groups 2-4 received 50, 100 and $200 \mathrm{mg} / \mathrm{kg}$ water extract, respectively for 2 days.

\section{Assay for in vitro lipid peroxidation}

To study the inhibition of lipid peroxidation by the extract, lipid peroxidation was induced with $\mathrm{Fe}^{2+}$ /ascorbate system. ${ }^{[11]}$ The reaction mixture contained liver homogenate $(25 \%, 0.1$ $\mathrm{ml})$ in Tris-HCl buffer $(0.2 \mathrm{M}, \mathrm{pH} 7.0)$, ascorbic acid $(0.3 \mathrm{mM})$, ferrous ammonium sulfate $(0.8 \mathrm{mM})$ and test extract $(0-100$ $\mu \mathrm{g} / \mathrm{ml}$ ) in the final volume of $0.5 \mathrm{ml}$. The incubation was carried out for $1 \mathrm{~h}$ at $37^{\circ} \mathrm{C}$. The lipid peroxide content was measured as thiobarbituric acid reactive substances by the method of Okhawa $e t$ al. ${ }^{[12]}$ The percentage of inhibition of lipid peroxide formation was determined by comparing the results of drug treated and untreated samples.

Assay for hydroxyl radical scavenging activity

Hydroxyl radical scavenging was measured by studying the competition between deoxyribose and the fern extracts for hydroxyl radical generated from the $\mathrm{Fe}^{3+}$-ascorbate-EDTAhydrogen peroxide system (Fenton reaction). The reaction mixture containing deoxyribose $(2.8 \mathrm{mM})$, ferric chloride $(0.1$ $\mathrm{mM})$, EDTA $(0.1 \mathrm{mM})$, hydrogen peroxide $(1.0 \mathrm{mM})$, ascorbate $(0.1 \mathrm{mM})$, potassium di-hydrogen phosphate-potassium hydroxide buffer (20 mM, pH 7.4) and various concentrations of the extracts in a final volume of $1 \mathrm{ml}$. The mixture was incubated for $1 \mathrm{~h}$ at $37^{\circ} \mathrm{C}$. Deoxyribose degradation was measured as thiobarbituric acid reactive substances by the method of Ohkawa et al. ${ }^{[12]}$.

Assay for in vivo lipid per-oxidation

To study the in vivo effect of the water extract on lipid peroxidation, male mice weighing 28-30 g were divided into control and test groups. There were three test groups; one for each plant species with six mice in each group. The test group was administered daily $100 \mathrm{mg} / \mathrm{kg}$ of water extract, p.o., $(0.5$ $\mathrm{ml} /$ mouse) for 6 days and the control group received the vehicle (water) in an identical manner. The animals were killed on the seventh day and the liver samples were collected. Liver homogenate was prepared and thiobarbituric acid reactive substances in the homogenate were measured as mentioned earlier.

\section{Short-term toxicity evaluation}

To determine the short-term toxicity, groups of eight male mice were administered daily, different doses of the active water extract of $S$. involvens for 15 days. Body weight, food and water intake, and general behaviour were monitored. The behavioural parameters observed were grooming, hyperactivity, sedation, loss of righting reflex, convulsion and respiratory rate. After the treatment period, mice were killed for the collection of blood and vital organs. The weights of the important organs were recorded. The haematological and serum biochemical parameters [protein, urea, cholesterol, glutamate pyruvate transaminase (GPT), glutamate oxaloacetate transaminase (GOT), alkaline phosphatase and glucose] were determined using the standard methods..$^{[13 \mid-115]}$

Statistical analysis

Statistical comparison was done with three or more groups using one-way analysis of variance (ANOVA) followed by Dunnetts' test. P values $<0.05$ were considered significant.

\section{Results}

\section{Extracts}

The dried powders of the three different ferns showed more or less the same pattern of extractability with water, ethyl alcohol and n-hexane. In the case of $S$. involvens, the yields as percentage of dry whole plant powder of water, ethyl alcohol and n-hexane extracts were $16.0 \pm 2.0,10.1 \pm 1.1$ and $5.0 \pm 0.6$, respectively. The yields for $S$. delicatula (water, ethyl alcohol and n-hexane) extracts were $24.2 \pm 3.2,14.1 \pm 2.2$ and $3.2 \pm 0.4$, respectively, whereas those for $S$. wightii extracts were $19.1 \pm 2.4,9.1 \pm 2.1$ and $2.2 \pm 0.2$, respectively. 
Effect of administration of water suspension of Selaginella species (whole plant powder) on thymus weight, blood leucocyte and peritoneal macrophage counts in mice

\begin{tabular}{|c|c|c|c|c|c|}
\hline Groups & & $\begin{array}{c}\text { Body weight } \\
g\end{array}$ & $\begin{array}{c}\text { Thymus weight } \\
\text { mg }\end{array}$ & $\begin{array}{l}\text { Peritoneal macrophages } \\
\text { (Cells/mouse) } \times 10^{-6}\end{array}$ & $\begin{array}{l}\text { Total leucocytes } \\
\text { (Cells/ml) } \times 10^{-6}\end{array}$ \\
\hline Control ( $1 \%$ gum acacia) & & $28.1 \pm 0.7$ & $30.5 \pm 5.2$ & $5.86 \pm 0.81$ & $10.0 \pm 0.8$ \\
\hline S. involvens $(500 \mathrm{mg} / \mathrm{kg})$ & & $27.1 \pm 0.6$ & $68.5 \pm 6.2^{* *}$ & $6.66 \pm 0.92$ & $9.2 \pm 0.7$ \\
\hline S. delicatula $(500 \mathrm{mg} / \mathrm{kg})$ & & $28.4 \pm 0.9$ & $46.6 \pm 5.5^{\star *}$ & $6.06 \pm 0.74$ & $9.6 \pm 0.9$ \\
\hline S. wightii $(500 \mathrm{mg} / \mathrm{kg})$ & & $27.9 \pm 0.8$ & $41.4 \pm 03.2^{*}$ & $5.96 \pm 0.61$ & $9.9 \pm 0.7$ \\
\hline One-way & $\mathrm{F}$ & & 65.3 & & \\
\hline \multirow[t]{2}{*}{ ANOVA } & df & & 3,20 & & \\
\hline & $\mathrm{P}$ & & $<0.001$ & & \\
\hline
\end{tabular}

$\mathrm{n}=6$ in each group. Values are mean $\pm S D$. The extract was administered, orally, daily for 6 days. ${ }^{*} \mathrm{P}<0.0 .05 ;{ }^{*} \mathrm{P}<0.001$ (Dunnett's test).

\section{Immunomodulation}

The crude water suspension of the whole plant powder (500 $\mathrm{mg} / \mathrm{kg}$ ) of the three plants did not influence humoral antibody titre and antibody secreting spleen cells against sheep RBC, antigens (data not shown). But, as shown in Table 1, the suspensions of the plants remarkably increased the weight of thymus in adult mice. This effect was very marked in the case of $S$. involvens compared to the other two species. The number of total leucocytes and peritoneal macrophages were not significantly altered by the treatments.

When different extracts of the ferns were tested, the water extract and not ethyl alcohol and n-hexane extracts, was found to stimulate the growth of thymus in mice. The increase in thymus weight observed in adult mice was remarkable in the case of $S$. involvens; it was more than 2 -fold at $100 \mathrm{mg} / \mathrm{kg}$, compared to control. [Table 2] However, this effect of the water extract was not observed in suckling mice (Table 3). The thymus stimulatory effect of the extract was dose-dependent and the effect was found to be optimum at $100 \mathrm{mg} / \mathrm{kg} S$. involvens (water extract) and it was prominent at $48 \mathrm{~h}$ after administration. [Table 3]

\section{Antioxidant activity}

The water extract of $S$. involvens showed remarkable inhibition of lipid per oxidation. This was found to be dosedependent. At a concentration of $2 \mu \mathrm{g} / \mathrm{ml}$ the in vitro inhibition of peroxidation of lipid was almost $50 \%$. The concentration required for $50 \%$ inhibition $\left(\mathrm{EC}_{50}\right)$ of in vitro lipid peroxidation for $S$. involvens, $S$. delicatula and $S$. wightii was $2.1 \pm 0.1$, $38.2 \pm 1.2$ and $76.6 \pm 4.4 \mu \mathrm{g} / \mathrm{ml}$ [mean \pm SD of 3 separate determinations], respectively. The water extract of the three plants also showed varying levels of hydroxyl radical scavenging activity in vitro. $S$. delicatula was more potent in hydroxyl radical scavenging activity compared to the other two species. Concentration of water extract required for $50 \%$ in vitro inhibition of hydroxyl radical production for $S$. involvens, $S$. delicatula and $S$. wightii was $170.2 \pm 7.2,32.1 \pm 2.6$ and $88.4 \pm 7.2 \mu \mathrm{g} / \mathrm{ml}$ [mean \pm SD of three separate determinations], respectively. This antioxidant activity was observed under in vivo conditions also. The liver homogenate obtained from the water extract $(100 \mathrm{mg} / \mathrm{kg})$ treated mice showed a marked reduction in thiobarbituric acid reactive substances (melondialdehyde formed from lipid peroxides) indicating in
Table 2

Effect of Selaginella species (water extract) on thymus gland weight in adult male mice

\begin{tabular}{|c|c|c|c|}
\hline \multirow{2}{*}{$\begin{array}{l}\text { Thymus weight }(\mathrm{mg}) \\
\text { Water extract treated } \\
(\mathrm{mg} / \mathrm{kg})\end{array}$} & \multicolumn{3}{|c|}{ Selaginella species } \\
\hline & S. involvens & S. delicatula & S. wightii \\
\hline Control (0) & $21.1 \pm 2.2$ & $20.8 \pm 3.0$ & $21.9 \pm 3.2$ \\
\hline 50 & $32.5 \pm 3.0^{* *}$ & $28.6 \pm 3.2^{*}$ & $26.4 \pm 4.0$ \\
\hline 100 & $49.9 \pm 5.1^{* *}$ & $35.6 \pm 4.4^{* *}$ & $31.3 \pm 3.4^{*}$ \\
\hline 200 & $44.8 \pm 4.3^{* *}$ & $36.4 \pm 3.7^{* *}$ & $34.0 \pm 2.0^{* *}$ \\
\hline One-way & 34.6 & 12. 3 & 8.2 \\
\hline \multirow[t]{2}{*}{ ANOVA } & 3,8 & 3,8 & 3,8 \\
\hline & $<0.001$ & $<0.001$ & $<0.01$ \\
\hline
\end{tabular}

Water extract of each fern was administered orally daily for 2 days and the mice were killed $24 \mathrm{hrs}$ after the second dose. Values are mean $\pm S$.D of three separate determinations. ${ }^{*} \mathrm{P}<0.0 .05 ;{ }^{*} \mathrm{P}<0.001$ compared to control (Dunnett's test).

vivo inhibition of lipid peroxidation. At the dose level studied $(100 \mathrm{mg} / \mathrm{kg})$ all the three plant extracts showed significant inhibition of lipid peroxide. Melondialdehyde formed in the control mouse liver homogenate was $1.10 \pm 0.08 \mathrm{n}$ mole/ $\mathrm{mg}$ protein whereas that formed in $S$. involvens, $S$. delicatula and $S$. wightii treated liver was $0.41 \pm 0.02 *, 0.51 \pm 0.03 *, 0.42 \pm$ $0.02 * \mathrm{n}$ mole/ $\mathrm{mg}$ protein, respectively [*P<0.001 compared to control].

Toxicity evaluation in mice

Daily feeding for 15 days with $S$. involvens (water extract) 200 or $400 \mathrm{mg} / \mathrm{kg}$ did not result in any change in general behaviour of the animals. Body temperature and state of the stool were also not influenced by the drug treatment. Weights of organs (liver, kidneys and spleen) as well as food and water intake were not significantly altered by the drug administration (data not given). The extract at $200 \mathrm{mg} / \mathrm{kg}$ dose markedly increased the weight of thymus, while at $400 \mathrm{mg} / \mathrm{kg}$ dose it marginally reduced the weight of thymus. [Table 4] The in vivo lipid peroxidation was also markedly reduced at $200 \mathrm{mg} / \mathrm{kg}$ dose, whereas at the higher dose $(400 \mathrm{mg} / \mathrm{kg})$ there was no significant change in lipid peroxidation. Blood haemoglobin content and leucocytes count, as well as serum protein, urea, GPT and GOT were unchanged by the treatment. [Table 5] 
Table 3

Effect of Selaginella involvens (water extract) administration for different time period on thymus gland weight in male mice belonging to different age groups

\begin{tabular}{|c|c|c|c|c|}
\hline \multirow{2}{*}{$\begin{array}{l}\text { Period of } \\
\text { treatment } \\
\text { (days) }\end{array}$} & & \multicolumn{3}{|c|}{$\begin{array}{c}\text { Thymus weight }(\mathrm{mg}) \\
\text { age of mice }\end{array}$} \\
\hline & & 3 weeks & 9 weeks & 15 weeks \\
\hline 0 (control) & & $48.5 \pm 6.2$ & $22.1 \pm 2.2$ & $12.2 \pm 2.2$ \\
\hline 1 & & $49.4 \pm 5.0$ & $31.9 \pm 3.8^{*}$ & $20.4 \pm 3.1^{*}$ \\
\hline 2 & & $51.7 \pm 7.2$ & $49.2 \pm 6.2^{\star *}$ & $34.2 \pm 4.1^{* *}$ \\
\hline 6 & & $50.1 \pm 5.9$ & $44.8 \pm 4.9^{* *}$ & $32.0 \pm 4.3^{* *}$ \\
\hline One-way & $\mathrm{F}$ & 0.14 & 10.00 & 25.38 \\
\hline \multirow[t]{2}{*}{ ANOVA } & df & 3,8 & 3,8 & 3,8 \\
\hline & $\mathrm{P}$ & $\mathrm{ns}<0.01$ & $<0.001$ & \\
\hline
\end{tabular}

Water extract $(100 \mathrm{mg} / \mathrm{kg})$ was administered, orally, daily. Values are Mean $\pm S D$ of three separate determinations. ${ }^{\star} P<0.0 .01 ;{ }^{*} \mathrm{P}<0.001$ (Dunnett's test).
Table 4

Effect of water extract of S. involvens (SI) on weights of body and thymus gland and lipid peroxidation in liver in short-term (15 days) toxicity study in mice

\begin{tabular}{lcccc}
\hline Groups & $\begin{array}{c}\text { Body } \\
\text { weight } \\
(\boldsymbol{g})\end{array}$ & $\begin{array}{c}\text { Weight of thymus } \\
\text { weight } \\
(\mathbf{m g})\end{array}$ & $\begin{array}{c}\text { Lipid } \\
\text { peroxidation } \\
\text { (n mole of MDA/ } \\
\text { mg protein) }\end{array}$ \\
\hline $\begin{array}{l}\text { Control } \\
\text { Treated }\end{array}$ & $27.1 \pm 1.6$ & $21.6 \pm 1.8$ & $1.08 \pm 0.07$ \\
SI $200 \mathrm{mg} / \mathrm{kg}$ & $26.9 \pm 1.9$ & $40.8 \pm 2.3^{* *}$ & $0.65 \pm 0.05^{* *}$ \\
Sl $400 \mathrm{mg} / \mathrm{kg}$ & $28.0 \pm 1.4$ & $15.1 \pm 1.2^{*}$ & $1.12 \pm 0.09$ \\
\hline One-way F & 0.14 & 315.22 & 101.30 \\
ANOVA & $\mathrm{df}$ & 2,15 & 2,15 & 2,15 \\
& $\mathrm{P}$ & $\mathrm{ns}$ & $<0.001$ & $<0.001$ \\
\hline
\end{tabular}

The extract was administered, orally, daily. Initial body weight was not significantly different between the three groups. MDA, Melandialdehyde. ${ }^{* *} \mathrm{P}<0.001$; ${ }^{*} \mathrm{P}<0.05$

\section{Table 5}

Effect of water extract of S. involvens (SI) on serum biochemical and hematological parameters in short-term (15 days) toxicity study in mice

\begin{tabular}{|c|c|c|c|c|c|c|c|c|c|c|}
\hline \multirow{2}{*}{\multicolumn{2}{|c|}{ Groups }} & \multicolumn{6}{|c|}{ Biochemical parameters } & \multicolumn{3}{|c|}{ Hematological parameters } \\
\hline & & $\begin{array}{l}\text { SGPT } \\
(I U / I)\end{array}$ & $\begin{array}{l}\text { SGOT } \\
(I U / I)\end{array}$ & $\begin{array}{c}A L P \\
(K A U)\end{array}$ & $\begin{array}{c}\text { Urea } \\
\text { (mg/dl) }\end{array}$ & $\begin{array}{l}\text { Cholesterol } \\
\text { (mg/dl) }\end{array}$ & $\begin{array}{l}\text { Glucose } \\
\text { (mg/dl) }\end{array}$ & $\begin{array}{c}H b \\
(m g \%)\end{array}$ & $\begin{array}{c}W B C \\
\left(10^{6} / \mathrm{ml}\right)\end{array}$ & $\begin{array}{r}\text { Macrophages } \\
\left(10^{6} / \text { mouse }\right)\end{array}$ \\
\hline \multicolumn{2}{|l|}{$\begin{array}{l}\text { Control } \\
\text { Treated }\end{array}$} & $26.3 \pm 2.2$ & $74.5 \pm 4.9$ & $9.5 \pm 1.8$ & $43.2 \pm 2.1$ & $126.3 \pm 4.2$ & $109.4 \pm 4.6$ & $13.5 \pm 0.6$ & $11.3 \pm 1.2$ & $8.5 \pm 0.2$ \\
\hline \multicolumn{2}{|c|}{ SI 200 mg/kg } & $25.1 \pm 2.2$ & $76.4 \pm 4.3$ & $10.1 \pm 1.8$ & $41.1 \pm 2.2$ & $113.2 \pm 5.1$ & $106.2 \pm 4.6$ & $14.0 \pm 0.6$ & $10.2 \pm 1.3$ & $8.9 \pm 0.3$ \\
\hline \multicolumn{2}{|c|}{ SI 400 mg/kg } & $29.8 \pm 2.2$ & $87.5 \pm 5.1$ & $14.7 \pm 1.5^{*}$ & $38.2 \pm 3.2$ & $73.2 \pm 4.1^{* *}$ & $119.9 \pm 4.6^{*}$ & $13.8 \pm 0.6$ & $11.0 \pm 1.2$ & $9.5 \pm 0.2^{*}$ \\
\hline One-way & $\mathrm{F}$ & 2.1 & 2.8 & 14.6 & 2.9 & 216.5 & 12.9 & 0.6 & 1.1 & 22.4 \\
\hline \multirow[t]{2}{*}{ ANOVA } & $\mathrm{df}$ & 2,15 & 2,15 & 2,15 & 2,15 & 2,15 & 2,15 & 2,15 & 2,15 & 2,15 \\
\hline & $P$ & ns & ns & $<0.01$ & ns & $<0.001$ & $<0.01$ & ns & ns & $<0.001$ \\
\hline
\end{tabular}

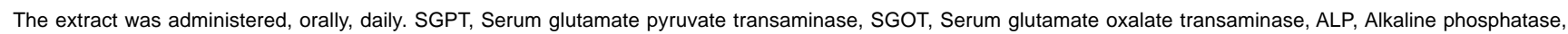
Values are mean \pm S.D.; $n=6$ in each group; ${ }^{*} P<0.05 ;{ }^{* *} P<0.01$ (Dunnett's test)

\section{Serum cholesterol}

Interestingly the level of serum cholesterol was significantly reduced in the high dose $(400 \mathrm{mg} / \mathrm{kg}$ ) treated mice. [Table 5]

The peritoneal macrophage count, serum glucose and alkaline phosphatase showed an increasing trend at the higher dose. Thus the water extract did not exhibit any conspicuous adverse toxic symptoms in the preliminary short-term general toxicity study in male mice.

\section{Discussion}

This is the first report on the pharmacological properties of Selaginella species. The present study shows that the water extract of $S$. involvens and, to some extent, that of $S$. delicatula and $S$. wightii can reverse thymic involution in the adult mice. Interestingly, the same extract has both reversions of thymus involution and antioxidant activities. These activities are linked to old age related health problems and reduction in life span. [16], [17] Involution of thymus is known to be one of the leading regulators of aging and age-dependent decline in thymus- dependent immune functions including removal of autoreactive T-cells. ${ }^{[16],[18]}$ Therefore, it appears as a promising fern to develop as an agent to prolong life span and reduce old age related health complications.

The observed increase in the weight of thymus appears to be due to both an increase in epithelial cells and the number of thymocytes. This may reflect an increase in the proliferation of thymic epithelial cells and chemotactic-mediated enhancement in the entry of precursor T-cells into the thymus. Histological studies on the thymus remain to be done to confirm this. The stimulation of thymus did not occur in suckling mice, where the involution has not occurred significantly. Autoreactive lymphocytes are eliminated by apoptosis in the thymus, which could prevent auto-immunity. ${ }^{[18]}$ The water extract could, possibly, prevent many old age related infections, auto-immunity, etc.

The mechanism by which the extract exerts its effect on the thymus is not known. Probably, it could indirectly stimulate thymic epithelial cells to proliferate leading to reversion of 
thymus involution. Many factors including growth factors are involved in the involution of thymus. ${ }^{[19]}$ The influence of the extract on these factors and the expression of their genes remain to be studied.

In the toxicity study, at high dose antilipid peroxidation activity was not observed. We do not know the reason for the same. It should be remembered that body produces varying levels of free radicals from different cell types. As an adaptation, macrophage may produce increased amount of free radicals to combat the antioxidant effect. The hypocholesteremic effect observed at high dose is also of interest. This observation requires detailed studies, among other things, using high cholesterol fed rats. It is possible that at high concentration, a shift in the metabolism of cholesterol and free radical production in the body may occur. The decrease in serum cholesterol levels and a marginal increase in macrophage number observed in the high dose treated animals are beneficial effects.

Many environmental toxic chemicals such as the dialkyl tin compounds used in plastic industry, cause thymic atrophy and subsequent immune suppression. ${ }^{[20]}$ It is of interest to study whether or not the water extract of Selaginella involvens could protect from such immuno-suppression. The thymic atrophy caused by dibutyl tin dilarate was associated with activation of protein kinase $\mathrm{C}$ and an increase in intracellular calcium in thymocytes and consequent inhibition of phosphoinositide turnover. ${ }^{[20]}$

Although many nutraceuticals and herbs have antioxidant activities, the antilipid per oxidation observed with the water extract of $S$. involvens in the present study was remarkable. More than $50 \%$ inhibition was observed at a very low concentration $(2 \mu \mathrm{g} / \mathrm{ml})$ of the extract. The well known natural product antioxidant curcumin showed activity far less than this. ${ }^{[21]}$ It should be noted that oxidative changes play a key role in various conditions, which limit the life span. ${ }^{[22]}$ Thus the herbal drug with reversal of thymus atrophy and remarkable antioxidant activity could possibly prove to be a boon in old age related health care.

$S$. involvens is used in ethnomedicine from time immemorial. Further, the extract did not show any conspicuous toxicity in our limited toxicity evaluation in mice. The doses used for the 15-day-toxicity studies were two and four times higher than the optimum dose required for stimulation of thymus weight in 2-day treatment. At the very high dose studied the stimulation of thymus growth was not evident. It is possible that some feedback control mechanism may come into effect at this high dose. In this connection the following points also need a mention.

1. There may be a possibility for development of tolerance to the thymic stimulation activity.

2. A possibility of inhibition (instead of stimulation) with chronic treatment exists.

3. This herbal drug if confirmed to be useful is more likely to be used on a chronic basis and hence future studies should focus on long-term treatment of this compound.

The herb appears to be a safe drug. There is an urgent need to carry on studies to establish the therapeutic utility of $S$. involvens as an invaluable medicine to treat specific old age related and toxic chemical mediated health problems. In view of the ethnomedical use of this fern for infection, there is a need to study the antimicrobial, including antiviral, properties also. Studies are in progress in this laboratory to isolate the active principle.

\section{Aknowledgments}

The authors acknowledge Mr. Raj Antony, Pteridophyte Taxonomist, Tropical Botanic Garden and Research Institute (TBGRI) for his help in the correct identification of the plants and Dr. G. M. Nair, Director, TBGRI, for his encouragement in the course of this research work. Kerala forest Department is gratefully acknowledged for providing financial help in the initial phase of the study. The authors express their sincere thanks to Mr. G. Santhoskumar, Animal House Technician, for providing technical assistance in the execution of animal experiments.

\section{References}

1. Kaushik P, Dhimian AK. Common medicinal pteridophytes. Indian Fern J 1995;12:139-44.

2. Dixit RD, Bhatt GK. Ferns: A much neglected group of medicinal plants II. J Res Indian Med 1974;9:59-68.

3. Manickam VS, Irudayaraj V. Pteridophytes flora of the Western Ghats- South India. New Delhi: BI Publications Pvt. Ltd. 54, Janapath; 1992.

4. Mathew PJ, Mathew Dan, Unnithan CM, Pushpangadan P. Ethno medical information of some pteridophytes of Kerala sector of Western Ghats. In: Biodiversity conservation and utilization of spices, medicinal and aromatic plants. Sasikumar B, Krishnamurthy B, Rema J, Ravindren PN and Peter KV, editors. Calicut: Indian Institute of Spices Research; 1999.

5. The Wealth of India. In: YR Chadha, editor. Vol. 9. New Delhi: CSIR Publication; 1972.

6. Sequiera KM. Diversity, systematics, distribution and taxonomy of epiphytic pteridophytes of Kerala part of Western Ghats, South India. Indian Fern J 1998;15:106-30.

7. Subramoniam DA, Evans S, Rajasekharan, Pushpangadan P. Hepatoprotective activity of Trichopus zeylanicus extract against paracetamol induced hepatic damage in rats. Indian J Exp Biol 1998;36:385-9.

8. Subramoniam A, Rajasekharan S, Latha PG, Evans DA, Pushpangadan P. Immunomodulatory and anti-tumor activities of Janakia arayalpathra. Fitoterapia 1996;57:140-4.

9. Subramoniam A, Evans DA, Rajasekharan S, Pushpangadan P. Effect of Trichopus zeylanicus Gaertn. (active fraction) on phagocytosis by peritoneal macrophages and humoral immune response. Indian J Pharmacol 2000;32:221-5.

10. Jerne NK, Nordin AA. Plague forming in agar by single antibody producing cells. Science 1963:40:405-7.

11. Bishayee S, Balasubramaniam AS. Assay of lipid peroxidation. J Neurochem 1971;18:909-13.

12. Okhawa $\mathrm{H}$, Ohishi $\mathrm{N}$, Yagi K. Assay for lipid peroxides in animal tissue by thiobarbutric acid reaction. Anal Biochem 1976;95:351-8.

13. Jam NC. Schalm's Veterinary haematology, $4^{\text {th }}$ ed. Philadelphia: Lea and Fabiger; 1986.

14. Reitman S, Frankel S. Calorimetric method for the determination of serum GPT, and GOT. Am J Cli Pathol 1960;28:56-63.

15. Henry RJ. Clinical chemistry: Principles and techniques. New York: Harper and Ron; 1974.

16. Aspinall R, Andrew D. Thymic involution in aging. J Clin Immunol 2000;20:2506.

17. Golden TR, Hinerfeld DA, Melov S. Oxidative stress and aging: Beyond correlation. Aging Cell 2003;1:117-23.

18. Bodey B, Bodey B Jr, Siegel SE, Kaiser HE. Involution of mammalian thymus, one of the leading regulators of aging. In vitro 1997;11:421-40.

19. Garcio-Suarez O, Perez-perez M, Germana A, Esteban I, Germana G. Involvement of growth factors in thymic involution. Microsc Res Tech 2003;62:51423.

20. Subramoniam A, Khandelwal S, Dwivedi P W, Khanna S, Shankar R. Dibutyltin dilaurate-induced thymic atrophy and modulation of phosphoinositide pathway of cell signaling in thymocytes of rats. Immunopharmacol. Immunotoxicol 1994;6:645-77.

21. Elizabeth $\mathrm{K}, \mathrm{Rao} \mathrm{M} N \mathrm{~A}$. Oxygen radical scavenging activity of curcumin. Int $\mathrm{J}$ Pharm 1990;58:237-40.

22. Droge W. Oxidative stress and aging. Adv Exp Med Biol 2003;543:191- 200. 